\title{
ИДЭВХЖҮҮЛСЭН НҮҮРСИЙГ ЕЕМ АНАЛИЗААР СУДАЛСАН ДҮН
}

\author{
А.Ариунаа ${ }^{1}$, Б.Пүрэвсүрэн ${ }^{1}$, Ч.Ганзорие ${ }^{2}$ \\ ${ }^{1}$ Шинжлэх Ухааны Академийн Хими, хими технологийн хүрээлэн, \\ a_a_ariunaa@yahoo.com, purevsuren_b@yahoo.com \\ ${ }^{2}$ МУИС-ийн Химийн факультет
}

\section{Хураангуй}

Нарийн сухайт, Алагтогоо, Шарын гол, Шивээ-Овоогийн ордын нүүрсний дээжийг сонгон авч техникийн үзүүлэлтүүд ба элементийн бүрэлдэхүүнийг нарийвчлан тодорхойлов. Эдгээр нүүрсийг пиролизод оруулж гарган авсан хатуу үлдэгдлийг усны уурын урсгалд идэвхжүүлж гарган авсан идэвхжүүлсэн нүүрсний йод шингээх багтаамж, гадаргуугийн талбайг тодорхойлж SEM-ийн анализын тусламжтайгаар нүх сүвэрхэг бүтиийг нь судлан тодорхойллоо.

Түлхүүр уе: Нүүрс, карбонжуулалт, идэвхжүүлсэн нүүрс, идэвхжүүлэлт

\section{ОРшИЛ}

Улаанбаатар хотын агаарын бохирдол, утааны асуудал болон Туул голын усны бохирдол гамшгийн хэмжээнд хүрээд байгаa [1] өнөө үед Монгол орны нөөц ихтэй нүүрс, мод, зэрэг түүхий эдийг идэвхжүүлэх аргыг боловсруулан, хатуулаг ихтэй ундны ус, үйлдвэрийн бохирдсон агаар ба хаягдал ус, хүнсний бүтээгдэхүүнийг цэвэрлэх зэрэг зориулалттай амьдрал ахуйн чухал хэрэгцээт идэвхжүүлсэн нүүрс гаргаж авах судалгааг гүйцэтгэх нь өнөөгийн нөхцөлд ихээхэн шаардлагатай байна. Идэвхжүүлсэн нүүрсийг мод, нүүрс, нефтийн үлдэгдэл, нийлэг материал гэх мэт түүхий эдээс гарган авч болдог ч нүүрс нь түүнийг гаргах хамгийн хямд түүхий эдэд тооцогддог [2]. Бид идэвхжүүлсэн нүүрс гарган авахын тулд судалгааны ажлын объект болгон Шивээ-Овоо, Шарын гол, Алагтогоо, Нарийн сухайтын нүүрсийг сонгон авсан болно. Судалгааны дээж болгон сонгон авсан 4 ордын нүүрсний талаархи мэдээлэлийг 1-р хүснэгтэнд үзүүлэв.

1-р хүснэгт

Судалгаанд хамрагдсан 4 ордын нүүрсний талаархи мэдээлэл

\begin{tabular}{|c|c|c|c|c|}
\hline № & $\begin{array}{c}\text { Нүүрсний } \\
\text { орд газрын } \\
\text { нэр }\end{array}$ & Байршил & Нүүрсний төрөл, анги, нөөц & $\begin{array}{c}\text { Нээсэн } \\
\text { он }\end{array}$ \\
\hline 1 & $\begin{array}{c}\text { Нарийн } \\
\text { сухайт }\end{array}$ & $\begin{array}{c}\text { Өмнөговь аймгийн } \\
\text { Гурвантэс сумын нутагт, } \\
\text { Даланзадгад хотоос 296 км, } \\
\text { Улаанбаатараас 849 км }\end{array}$ & $\begin{array}{c}\text { Дээд шатны чулуун нүүрсийг 9 давхарга } \\
\text { илрүүлснээс одоогоор I, V давхаргыг } \\
\text { үйлдвэрлэлийн ач холбогдолтойд } \\
\text { тооцож олзборлон Хятад руу гаргаж } \\
\text { байгаа. Ордын геологийн нийт нөөц } \\
125,5 \text { сая.т. }\end{array}$ & 1994 \\
& & $\begin{array}{c}125,5 \\
\end{array}$ & \\
\hline
\end{tabular}




\begin{tabular}{|c|c|c|c|c|}
\hline 2 & Алагтогоо & $\begin{array}{c}\text { Дорноговь аймгийн } \\
\text { Даланжаргалан сумын } \\
\text { нутагт, сумын төвөөс баруун } \\
\text { хойш 26 км -т байрладаг } \\
\text { Улаанбаатараас 300 км },\end{array}$ & $\begin{array}{c}\text { Доод шатны чулуун нүүрс 872 сая тонн } \\
\text { нөөцтэй }\end{array}$ & - \\
\hline 3 & Шарын гол & $\begin{array}{c}\text { Дархан хотоос хойш } 80 \text { км } \\
- \text { т оршдог }\end{array}$ & $\begin{array}{c}\text { Доод шатны чулуун нүүрс } 69,9 \text { сая тонн } \\
\text { нөөцтэй }\end{array}$ & 1965 \\
\hline 4 & Шивээ- & $\begin{array}{c}\text { Дорноговь аймгийн Сүмбэр } \\
\text { Сумын нутагт төмөр замын } \\
\text { Чойр станцаас урагш 20 } \\
\text { км-т оршдог }\end{array}$ & $\begin{array}{c}\text { Доод цэрдийн насжилттай хүрэн } \\
\text { нүрсний 8 давхаргад 2,7 тэрбум тонн } \\
\text { геологийн нөөцтэй ба үйлдвэрлэлийн } \\
\text { нөөц нь 564,1 сая.т }\end{array}$ & 1992 \\
\hline
\end{tabular}

Бидний судалгааны ажлын обьект болгон сонгож авсан 4 ордын нүүрсний талаар манай орны эрдэмтэд, судлаачид 1960 аад оноос эхлэн судалж тухайлбал 1970 -аад онд С.Долгор нар Шарын голын нүүрсийг исэлдүүлж ургамал, амьтны өсөлтийг идэвхжүүлэгч -нитрогумат гарган авч, Зүүнхараа, Дэвшил, Батсүмбэрийн сангийн аж ахуйд хэрэглэн туршиж үйлдвэрлэлд нэвтрүүлсэн [3,4 ] .

Э.Нордов Шарын голын нүүрсний найрлага бүтэц, халуун задралын механизм, ерийн ба исэлдсэн нүүрсний гумины хүчлийн химийн бүтэц, биологийн идэвхийг судалжээ [5].

Д.Жамбал Шарын голын нүүрсний сульфожих урвалыг судалж хүхэржүүлсэн нүүрсийг хэрэглэх чиглэлийн талаар судалсан байна [6].

Я.Даваажав, Б. Пүрэвсүрэн нар Алагтогоогийн ордын нүүрсний шинж чанар ба пиролизын судалгааг явуулж [7], Ж.Нарангэрэл Нарийн сухайт, Шарын голын нүүрсийг $\mathrm{CO}_{2}$-оор идэвхжүүлэн азотын хүчлээр исэлдүүлж шинэ төрлийн шингээгч материал гарган авч шингээх шинж чанарыг нь судласан [8] бол Б.Авид ШивээОвоогийн нүүрсний пиролизын болон хийжүүлэлтийн процессыг судалсан байна [9].

Мөн Б.Пүрэвсүрэн нарын судлаачид органик түүхий эдээс шингээгч, шүүгч материал гарган авах технологи төсөлт ажлын хүрээнд өөрсдийн зохион бүтээсэн органик түүхий эдүүдийг нүүрсжүүлэн идэвхжүүлэх лабораторийн ба томруулсан туршилтын зуухан төхөөрөмжийн тусламжтайгаар усны уураар идэвхжүүлж эдгээр 4 янзын нүүрснээс шингээгч, шүүгч материал гарган авч шинж чанарыг судлан тогтоох ажлыг нилээд өргөн хүрээнд гүйцэтгэж эхэлсэн билээ [10].

Ажлын зорилго нь Шивээ-Овоо, Шарын гол, Алагтогоо, Нарийн сухайт зэрэг ордын нүүрсний найрлага, шинж чанар,карбонжуулалтын бүтээгдэхүүний шинж чанар ба түүнийг химийн ба физик аргаар идэвхжүүлж нүх сүвэрхэг бүтцийг нь анх удаа электрон микроскопийн ( SEM) аргаар судлахад оршино.

\section{Материал, судалгааны арга зүй}

Судалгааны дээж: Монгол орны Шивээ-Овоо, Алагтогоо, Шарын гол ба Нарийн сухайтын ордын нүүрсийг холбогдох стандартын дагуу аналитик дээж бэлтгэж судалгаанд ашиглав.

Нүүрсний техник болон элементийн анализын арга зүй: Нүүрсний чийглэгийг УСТ 655-72, үнслэгийг УСТ 652-72, дэгдэмхий бодисын агуулгыг УСТ 654-72, хүхрийн хэмжээг УСТ 656-72, илчлэгийг УСТ 669-72 стандартын дагуу тодорхойлсон. Нүүрс болон коксын элементийн найрлагыг Эрхүүгийн Химийн 
институт болон Томскийн Нефть химийн институтэд тодорхойлсон.

Карбонжуулалтын судалгааны арга зүй: Карбонжуулалтыг Хими, химитехнологийн хүрээлэнгийн нүүрсний химийн лабораторийн ган реторттой карбонжуулалтын СНОЛ маркийн цахилгаан зууханд явуулав. Аргачлал: Туршилтыг явуулахдаа уламжлалт арга ашиглан Шивээ-Овоо, Шарын гол, Алагтогоо ба Нарийн сухайтын нүүрсийг хацарт бутлуурын тусламжтайгаар бутлан 3-1.5 мм ширхэглэлтэйгээр фрракцалж ялгаад, карбонжуулалтын ретортонд ойролцоогоор 300 г-ыг хийж ретортоо таглана. Босоо байрлалтай СНОЛ маркийн цахилгаан зуухан дотор ретортоо хийгээд $20^{\circ} \mathrm{C}$ мин $^{-1}$ хурдтайгаар халаан туршилтуудыг явуулав. Реторт

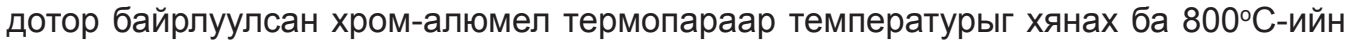
температурт шингэн бүтээгдэхүүн ялгарч бүрэн дуусах хүртэл карбонжуулалтыг 270 минут, агааргүй орчинд явуулна. Карбонжуулалтын бүтээгдэхүүнүүд болох хатуу үлдэгдэл, давирхай, задралын ус, хий зэргийг жингийн аргаар тодорхойлно.

Нүүрсийг идэвхжүүлэх судалгааны арга зүй: Шивээ-Овоо, Шарын гол, Алагтогоо, ба Нарийн сухайтын ордын коксыг 1.5-0.63мм болгон фрракцлан ялгаж, 10г коксын дээж аван, кварцан босоо реакторт 100\% усны ханасан уурын урсгалд $\left(160 \mathrm{~cm}^{3}\right.$ мин $\left.^{-1}\right), 800^{\circ} \mathrm{C}$ температурт (халаах хурд $5^{\circ} \mathrm{C}$ мин $\left.^{-1}\right), 60,100,140,180,220$ минут хугацаатай тус тус идэвхжүүлсэн болно. Идэвхжүүлэлтэнд Англи улсын Нүүрстөрөгчийн судалгааны лабораторид боловсруулсан аргачлал ашигласан. Карбонжуулалтанд оруулсан ба идэвхжүүлсэн бүтээгдэхүүнүүдийг тус тусд нь ШОК, ШГК, АТК, НСК, ба ШОИН, ШГИН, АТИН, НСИН гэж тэмдэглэв.

Идэвхжүүлсэн нүүрсний шингээлтийг йодын тоогоор шалгах арга: Идэвхжүүлсэн нүүрсний шингээлтийг (ГОСТ 6217-74) стандарт аргын дагуу шингээх багтаамжийг тодорхойлсон. Йодын 0.1 н уусмал бэлтгэнэ. 1 г нүүрсний дээж аван 50 мл йодын уусмал нэмэн, 15 минут сэгсрээд, 5 минут тайван байлган, 0.5\% -ын крахмалын уусмалаас 1-2 мл нэмэн, $0.1 \mathrm{H} \mathrm{Na} \mathrm{S}_{2} \mathrm{O}_{3}$ уусмалаар хөх өнгө алга болтол титэрлэнэ. Йод шингээлтийг дараах (1) томъёогоор тооцно.

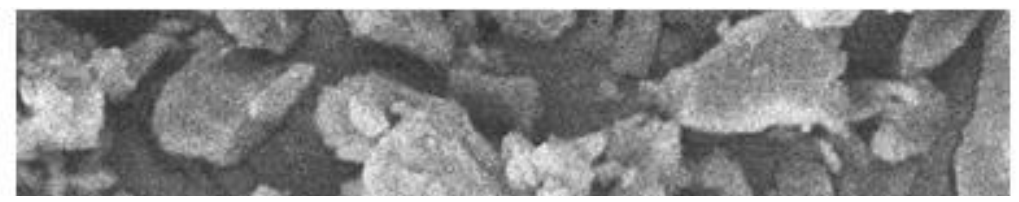

Үүнд: $\mathrm{V}_{1}$-тиосульфатын зарцуулалт, мл

$\mathrm{V}_{0}$ - хоосон туршилтын тиосульфатын зарцуулалт, мл

$\mathrm{m}$ - дээжний жин, г

a - дээжин дээр нэмсэн 0,1 н йодын уусмалын эзлэхүүн, мл

\section{Идэвхжүүлсэн нүүрсний гадаргуугийн талбай тодорхойлох арга зүй}

Шивээ-Овоо, Шарын гол, Алагтогоо, Нарийн сухайтын ордуудын идэвхжүүлсэн нүүрсний гадаргуугийн талбайг тодорхойлох судалгааны ажлыг Засгийн газрын хэрэгжүүлэгч агентлаг, Ашигт малтмалын газрын Нүүрсний туршилт судалгааны төв лабораторид, JW-K багаж нь дээр хийж гүйцэтгэв. Дээжийг U хэлбэртэй шилэн хоолойд байрлуулан багажид холбоод $\mathrm{N}_{2}$-Не хийн хольцыг нэвтрүүлнэ. Шилэн хоолойг шингэрүүлсэн азотод дүрэх үед хийн хольцод буй $\mathrm{N}_{2}$ нь дээжийн гадаргуу, нүх сүвд шингээгдэх ба хоолойг шингэрүүлсэн азотоос гаргах үед шингээгдсэн 
$\mathrm{N}_{2}$ хий нь буцаж ялгарна. Шингээгдсэн ба ялгарсан $\mathrm{N}_{2}$ хийн эзлэхүүнээр дээжийн гадаргуугийн талбайг тодорхойлно. Энэ багаж нь 1) үндсэн хэсэг, 2) дээж хатаах хэсэг, 3) компьютер, 4) дагалдах хэрэгслүүд болох азот ба гелийн хийн баллонууд, шилэн ба резин эд ангиуд, шингэн азот хадгалах баллон, вакуум насос, Дьюарын аяганаас бүрдэнэ. Үндсэн хэсэгт хэмжилтийн тохируулга хийх товчлуурууд, удирдлагын дэлгэц, дээжийг багажтай холбох эд ангиуд багтана. Энд дээжээ холбон хэмжилтийн тохируулгыг хийдэг. Дээж хатаах хэсэг нь дээжийг $105^{\circ} \mathrm{C}$ температурт, вакуум насосоор хатаах зориулалттай ба хатаах зуух, мини вакуум насосоос бүрдэнэ. Компьютер нь өгөгдлүүдийг оруулах, хэмжилтийг эхлүүлэх, үр дүнг боловсруулах, хадгалах, хэмжилтийг дуусгах удирдлагын зориулалттай. Дагалдах хэрэгслүүд туршилтыг азот ба гелийн хийгээр хангах, дээжийг шингэн азотоор хөргөх үндсэн зориулалттай.

Шууд харьцуулах арга ашиглан идэвхжүүлсэн нүүрстөрөгчийн гадаргуугийн талбайг тодорхойлсон. Идэвхжүүлсэн нүүрстөрөгчийн стандарт дээж 1, туршиж байгаа 1 дээж аваад адсорбцийн болон десорбцийн туршилт хийх ба туршиж байгаа дээжний адсорбцийн талбайг $\mathrm{A}_{x}$ хэмжилтээр олоод стандарт дээжний $\mathrm{A}_{0}-г$ ашиглан, доорхи тэгшитгэлээр туршиж байгаа дээжний гадаргуугийн талбай $\mathrm{Sg}_{\mathrm{x}}-г$ олно.

$$
S_{x}=\frac{A_{x} \times W_{0}}{A_{0} \times W_{x}} \times S_{0}
$$

(2).

Энд: $\quad \mathrm{A}_{\circ}$ ба $\mathrm{A}_{x}$ Стандарт болон туршиж байгаа дээжний десорбцийн талбай

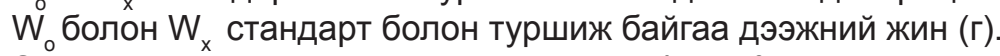

$\mathrm{Sg}_{\circ}$ стандарт дээжний гадаргуугийн талбай $\left(\mathrm{M}^{2} / г\right)$.

Стандартын болон шинжилж буй дээжүүдэд эхлээд азот адсорбцлогдох ба үүний дараа дээж тус бүрийг дараалан шингэрүүлсэн азоттай Дьюарын аяганаас гаргах үед десорбц явагдана. Десорбцийн муруйнууд нь багажны компьютерийн дэлгэцэд гарах ба десорбцийн муруйн талбайн хэмжээг харьцуулах тооцоог программ гүйцэтгэн эцсийн хариуг дэлгэцэнд харуулдаг.

\section{Идэвхжүүлсэн нүүрсний нүх сүвэрхэг бүтцийг электрон микроскопоор тодорхойлох арга зүй}

Шивээ-Овоо, Шарын гол, Алагтогоо, Нарийн сухайт зэрэг ордын 220 минут хугацаатай идэвхжүүлсэн нүүрсний (ШОИН220, АТИН220, ШГИН220, НСИН220) нүх сүвэрхэг чанарыг электрон микроскопоор (scanning electron microscope SEM) судаллаа. Бид уг судалгааг хийхдээ Монгол улсын их сургуулийн Химийн факультетийн Нано хими технологийн тэнхимийн Анализын лабораторид SEM электрон микроскопийг ашиглав. Уг электрон микроскоп нь Япон улсын Nikkiso компанид үйлдвэрлэсэн, SEMTRAC mini SM-3000 маркийн, өндөр вакуум орчинд, Second Electron детектортай, 20-30.000 дахин хүртэл өсгөлттэй, 20кВ хүчдэлтэй багаж болно. Сорьц бэлтгэхдээ дээж бүрээс 3 сорьц авч дээж тогтоогч дээр байрлуулсаны дараa Ion Sputter дээр 1 минут алтаар бүрсэн. Бүрсэн алтны = үеийн зузаан нь 5-10 нм болно. 


\section{Судалгааны үр дүн}

Судлахаар сонгож авсан 4 ордын нүүрсний дээжүүдийн техникийн үндсэн үзүүлэлтүүд ба элементийн найрлагыг тодорхойлсон үр дүнг 2 ба 3-р хүснэгтэнд үзүүлэв.

2-р Хүснэгт

Судалгаанд авсан дээжүүдийн техникийн шинжилгээний дүн

\begin{tabular}{|c|c|c|c|c|c|}
\hline \multirow{2}{*}{ № } & \multirow{2}{*}{ Дээж } & \multicolumn{4}{|c|}{ Техникийн үзүүлэлтүүд, \% } \\
\cline { 2 - 5 } & & Чийг, $\mathrm{W}^{\mathrm{a}}$, & Үнс, $\mathrm{A}^{\mathrm{d}}$, & $\begin{array}{c}\text { Дэгдэмхий бодис, } \\
\mathrm{V}^{\text {daf }},\end{array}$ & $\begin{array}{c}\text { Илчлэг, } \\
\mathrm{Q}^{\mathrm{daf}}, \text { ккал/кг }\end{array}$ \\
\hline 1 & Шивээ-Овоо & 10.89 & 18.07 & 46.79 & 5306 \\
\hline 2 & Шарын гол & 6.93 & 7.67 & 36.81 & 6640 \\
\hline 3 & Алагтогоо & 5.36 & 8.13 & 46.96 & 7257 \\
\hline 4 & Нарийн сухайт & 1.65 & 3.69 & 32.90 & 7998 \\
\hline
\end{tabular}

Судалгаанд авсан дээжүүдийн элементийн шинжилгээний дүн

\begin{tabular}{|c|c|c|c|c|c|c|}
\hline \multirow{2}{*}{ № } & \multirow{2}{*}{ Дээж } & \multicolumn{4}{|c|}{ Элементийн найрлага, \% } & \multirow{2}{*}{$\begin{array}{c}\text { H/C атомын } \\
\text { харьцаа }\end{array}$} \\
\hline & & $\mathrm{C}^{\text {daf }}$ & $\mathrm{H}^{\text {daf }}$ & $\mathrm{S}_{\mathrm{t}}^{\mathrm{daf}}$ & $\mathrm{N}+\mathrm{O}^{\mathrm{a}}$ & \\
\hline 1 & Шивээ-Овоо & 67.07 & 5.74 & 0.62 & 26.57 & 1.03 \\
\hline 2 & Шарын голын & 74.8 & 5.32 & 0.88 & 19.0 & 0.85 \\
\hline 3 & Алагтогоо & 75.87 & 5.22 & 0.53 & 18.38 & 0.83 \\
\hline 4 & Нарийн сухайт & 84.85 & 4.53 & 0.82 & 9.80 & 0.64 \\
\hline
\end{tabular}

а. хүчилтөрөгч ба азотыг ялгавраар тооцов.

2-3 -р хүснэгтээс харахад, Шивээ-Овоогийн ордын нүүрс нь чийглэг $W^{a}=10.89 \%$, дэгдэмхий бодис $\mathrm{V}^{\mathrm{daf}}=46.79 \%$, нүүрстөрөгчийн агуулга $\mathrm{C}^{\mathrm{daf}}=67.07 \%$ байгаа нь уг ордын нүүрс нь Б2 маркийн хүрэн нүүрс болохыг харуулж байна. Шивээ-Овоогийн нүүрсний хүхрийн хэмжээ $\mathrm{S}_{t}^{\text {daf }}=0.62 \%$ байгаа нь харьцангуй бага агуулгатайд тооцож болохоор байгаа учир энэ нүүрсийг цахилгаан станцуудад шатааж хэрэглэхэд боломжтой. Алагтогоогийн ордын нүүрс нь үнс $\mathrm{A}^{\mathrm{d}}=8.13 \%$, дэгдэмхий бодис $\mathrm{V}$ daf $=$ $46.96 \%$, нүүрстөрөгчийн агуулга $\mathrm{C}^{\mathrm{daf}}=75.87 \%$ байгаа нь Д маркийн чулуун нүүрс, Нарийн сухайтын ордын нүүрсний үнс $A^{d}=3.69 \%$, дэгдэмхий бодис $V^{d a f}=32.90 \%$, нүүрстөрөгчийн агуулга $\mathrm{C}^{\mathrm{daf}}=84.85 \%$, байгаа нь Г маркийн чулуун нүүрс болохыг илтгэж байна.

Нарийн сухайтын Г маркийн чулуун нүүрс, Шарын гол Б3-Д, Алагтогоогийн Д маркийн чулуун нүүрс ба Шивээ-Овоогийн хүрэн нүүрсний 3-1.5 мм-ийн

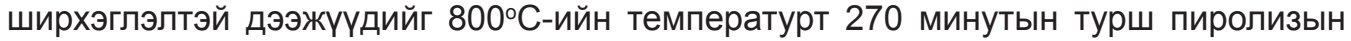
ретортонд карбонжуулан гарган авсан хатуу, шингэн ба хийн бүтээгдэхүүнүүдийн гарцыг тодорхойлсон үр дүнг 4-р хүснэгтэнд үзүүлэв. 
Нүүрсний карбонжуулалтын үр дүнгүүд

4-р хүснэгт

\begin{tabular}{|c|c|c|c|c|c|}
\hline \multirow{2}{*}{ № } & \multirow{2}{*}{ Дээж } & \multirow{2}{*}{$\begin{array}{c}\text { Карбонжуулалтын } \\
\text { температур, }{ }^{\circ} \mathrm{C}\end{array}$} & \multicolumn{3}{|c|}{ Карбонжуулалтын бүтээгдэхүүний гарц, \% } \\
\hline & & & Кокс & Давирхай+ус & Хий \\
\hline 1 & Шивээ-Овоо & 800 & 50.11 & 26.29 & 23.6 \\
\hline 2 & Шарын голын & 800 & 64.04 & 16.46 & 19.5 \\
\hline 3 & Алагтогоо & 800 & 58.85 & 19.82 & 21.33 \\
\hline 4 & Нарийн сухайт & 800 & 70.10 & 13.57 & 16.33 \\
\hline
\end{tabular}

3 болон 4-р хүснэгтээс харахад, Нарийн сухайтын нүүрсийг Алагтогоо, Шарын гол, Шивээ-Овоогийн нүүрстэй харьцуулахад нүүрстөрөгчийн агуулга өндөртэй (органик массад тооцоход $\mathrm{C}^{\mathrm{daf}}=84.85 \%$ ) тул арай илүү нүүрсжсэн чулуун нүүрс болохыггэрчилжбайна. Молекулынбүтцийнхувьдароматикцагирагуудньхоорондоо нүүрсустөрөгчдийн харьцангуй богино гинжээр холбогдох учраас халуун задралын үед карбонжуулалтын давирхайн гарц бага, хатуу үлдэгдлийн гарц их, шингэрээгүй хийн бүтээгдэхүүний гарц харьцангуй бага байна. Алагтогоогийн ордын Д ба Шарын голын ордын Б3-Д маркийн чулуун нүүрсний дэгдэмхий бодисыг органик массад тооцоход $V^{\text {daf }}=46.96 \%$ ба $\bigvee^{\text {daf }}=36.81 \%$ (2-р хүснэгт) байгаa нь Алагтогоогийн нүүрс нь Шарын голын нүүрсийг бодвол халууны тэсвэрлэлт арай багатай бодисуудаас тогтож байгаа учир агааргүй орчинд халуун задралд оруулснаар харьцангуй урт нүүрсустөрөгчдийн хэлхээ нь задарч халуун задралын давирхайн гарц арай их, хатуу үлдэгдлийн гарц бага, шингэрээгүй хийн бүтээгдэхүүний гарц арай их байна [11]. Нарийн сухайт, Шарын гол, Алагтогоо зэрэг чулуун нүүрс витринит ихтэй, инертинит багатай учир ийм төрлийн нүүрсийг агааргүй орчинд халаахад их хэмжээгээр хөөж халуун задрал явагдаж задралын бүтээгдэхүүнүүд зайлуулагдсаны дараа тодорхой бөх бат чанартай нүх сүвэрхэг бүтэц бүхий бүхэллэг хатуу үлдэгдэл буюу кокс үүсгэдэг [12] учир цаащид халуун химийн аргаар боловсруулж шингээх чадвар сайтай идэвхжүүлсэн нүүрс гарган авах боломжтой. Шивээ-Овоогийн ордын хүрэн нүүрсийг дээрх ордын нүүрстэй харьцуулахад нүүрсний дэгдэмхий бодисыг органик массад тооцоход $\mathrm{V}^{\mathrm{daf}}=46.79 \%$, нүүрсустөрөгчийн атомын харьцаа H/C харьцангуй их 1.03\% байгаа нь молекулын бүтцийн найрлаганд алифатик бүтэц голдуу зонхилдог, липтинит ихтэй нүүрс учир түүнийг халуун задралд оруулснаар амархан задарч шингэн бүтээгдэхүүн ба хийн гарц өндөртэй байдаг байна [13,14]. Иймд Шивээ-Овоогийн нүүрсний устөрөгчжүүлэн шингэн түлш гарган авахад боломжтой. Нарийн сухайтын Г маркийн чулуун нүүрс, Шарын голын Б3-Д, Алагтогоогийн Д маркийн чулуун нүүрс ба Шивээ-Овоогийн хүрэн нүүрсний 3-1.5 мм-ийн ширхэглэлтэй дээжүүдийг 800 C-ын температурт 270 минутын турш карбонжуулалтын ретортонд нүүрсжүүлэн гарган авсан коксын техникийн шинж чанар болон элементийн найрлагыг тодорхойлсон үр дүнг 5-р хүснэгтэнд үзүүлэв.

5-р хүснэгтээс харахад, нүүрсний халууны задралаар кокс буюу хатуу үлдэгдэл дэх үнслэгийн хэмжээ нэмэгдэж, дэгдэмхий бодисын агуулга эрс буурсан байна. Дэгдэмхий бодисын гарцууд маш ихээр багассан нь нүүрсний дээжүүд өндөр температурт гүнзгий задралд орсныг харуулж байна. 


\section{Коксын техникийн шинж чанар болон элементийн найрлага}

5-р хүснэгт

\begin{tabular}{|c|c|c|c|c|c|c|c|c|c|}
\hline \multirow[t]{2}{*}{ № } & \multirow[t]{2}{*}{ Дээж } & \multicolumn{3}{|c|}{$\begin{array}{c}\text { Техникийн үзүүлэлтүүд, } \\
\%\end{array}$} & \multicolumn{5}{|c|}{ Элементийн найрлага, \% } \\
\hline & & $W^{a}$ & $A^{d}$ & $V^{d a f}$ & $\mathrm{C}^{\text {daf }}$ & $\mathrm{H}^{\mathrm{daf}}$ & $\mathrm{S}_{\mathrm{t}}^{\mathrm{daf}}$ & $\mathrm{N}^{\mathrm{daf}}$ & $\mathrm{O}^{\mathrm{a}}$ \\
\hline 1 & Шивээ-Овоо & 1.91 & 21.04 & 5.18 & 90.81 & 3.32 & - & 0.92 & 5.85 \\
\hline 2 & Шарын гол & 0.98 & 17.72 & 2.41 & 90.82 & 2.91 & 0.63 & 0.58 & 5.06 \\
\hline 3 & Алагтогоо & 0.45 & 12.15 & 1.1 & 92.0 & 2.71 & 3.0 & 0.84 & 1.45 \\
\hline 4 & Нарийн сухайт & 0.48 & 4.6 & 1.1 & 94.0 & 2.45 & 0.20 & 0.76 & 9.01 \\
\hline
\end{tabular}

Шивээ-Овоогийн хүрэн нүүрс, Шарын гол Б3-Д, Алагтогоо Д, Нарийн сухайт Г маркийн чулуун нүүрсийг карбонжуулалтанд оруулсаны дараа коксыг 1.5-0.63 мм ширхэгтэй болгон фрракцлан ялгаж, дээжийг кварцан босоо реакторт усны уурын урсгалд $800^{\circ} \mathrm{C}$ температурт (халаах хурд $5^{\circ} \mathrm{C}$ мин $^{-1}$ ), 60, 100, 140, 180, 220 мин тус тус идэвхжүүлсэн үр дүнг 6-р хүснэгтэнд харуулав.

6-р хүснэгт

Нүүрсний коксыг $800^{\circ} \mathrm{C}$-д усны уураар идэвхжүүлсэн үр дүн

\begin{tabular}{|c|c|c|c|c|c|c|c|c|}
\hline № & Дээж & 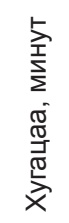 & 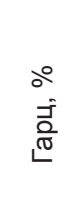 & $\begin{array}{l}\text { 논 } \\
\Sigma \\
\circ \\
\circ \\
\circ \\
\text { I } \\
\text { I } \\
\stackrel{0}{\circ}\end{array}$ & 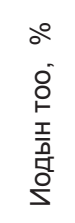 & 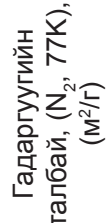 & 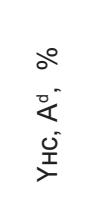 & 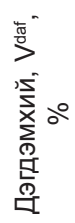 \\
\hline 1 & ШОК & - & - & 67 & 21.0 & - & 21.04 & 5.18 \\
\hline 2 & шОИн220 & 220 & 22.6 & 76 & 24.1 & 643 & 26.5 & 7.3 \\
\hline 3 & ATK & - & - & 4 & 1.1 & - & 12.2 & 1.1 \\
\hline 4 & АТИН60 & 60 & 89.7 & 30 & 9.3 & - & 12.2 & 1.6 \\
\hline 5 & АТИН100 & 100 & 84.8 & 48 & 15.1 & - & 12.8 & 2.0 \\
\hline 6 & АТИН140 & 140 & 78.8 & 157 & 35.7 & - & 16.3 & 2.3 \\
\hline 7 & АТИН180 & 180 & 67.5 & 159 & 36.2 & 711 & 24.3 & 2.4 \\
\hline 8 & АТИН 220 & 220 & 49.9 & 120 & 39.5 & 504 & 18.28 & 3.12 \\
\hline 9 & ШГК & - & - & 44 & 13.9 & - & 17.7 & 2.4 \\
\hline 10 & ШГИН220 & 220 & 74.7 & 113 & 35.6 & 430 & 19.1 & 2.7 \\
\hline 11 & $\mathrm{HCK}$ & - & - & 4 & 1.3 & - & 4.6 & 1.1 \\
\hline 12 & НСИН60 & 60 & 98.6 & 5 & 1.6 & 19 & 6.0 & 1.6 \\
\hline 13 & НСИН100 & 100 & 91.1 & 31 & 9.7 & 61 & 5.2 & 1.6 \\
\hline 14 & НСИН140 & 140 & 85.5 & 86 & 27.2 & 132 & 5.1 & 1.6 \\
\hline 15 & НСИН180 & 180 & 66.1 & 420 & 60.7 & 615 & 7.1 & 1.9 \\
\hline 16 & НСИН220 & 220 & 65.7 & 226 & 53.2 & 401 & 6.47 & 2.38 \\
\hline
\end{tabular}


6-р хүснэгтээс харахад идэвхжүүлсэн нүүрс гарган авах температур тогтмол үед $\left(800^{\circ} \mathrm{C}\right)$, идэвхжүүлэх хугацааг ихэсгэхэд идэвхжүүлсэн нүүрсний үнс болон дэгдэмхий бодисын агуулга нүүрсний кокстой харьцуулахад ихэсч байна. Энэ нь нүүрсний органик масс задарч органик бус бүрэлдэхүүний агуулга харьцангуй ихэссэн, задралаас үүссэн чөлөөт радикалууд усны уурын хүчилтөрөгчтэй нэгдэж исэлдэх урвал явагдаж байгаатай холбоотой юм [15,16].

Нүүрсийг карбонжуулалтанд оруулах үед нүүрсний коксын зарим нүх сүвүүдэд задралын бүтээгдэхүүний тодорхой хэсгүүд орж бөглөх боломжтой. Харин коксыг $800^{\circ} \mathrm{C}$ температурт усны уураар үлээлгэхэд эдгээр бөглөөтэй байсан нүх сүвүүд чөлөөлөгдөж олон ан цав сүв үүсч байгаа гэж үздэг.

Нүүрсний коксыг усны уурын урсгалд идэвхжүүлэх явцад идэвхжүүлэлтийн хугацааг ихэсгэх тутам хатуу бүтээгдэүүний гарц багасч байна. Энэ нь нүүрсний органик бодисын исэлдэлт буюу задралын процесс үргэлжлэн явагдаж түүний жин нь багасч байгаатай шууд холбоотой гэж үзэж байна. Идэвхжүүлэлтийн хугацаа урт байх нь идэвхжүүлсэн нүүрсний шинж чанарт ерөнхийдөө эерэгээр нөлөөлдөг боловч түүний гарцыг багасгах сөрөг нөлөөтэй байна. Иймд хамгийн тохиромжтой хугацааг олж тогтоох нь ялангуяа үйлдвэрлэлийн процесст ихээхэн чухал болно.

Нүүрсжүүлэн идэвхжүүлсэн материалын нүх сүвэрхэг чанарыг судлахад электрон микроскопийн аргыг хамгийн их хэрэглэдэг. Иймд бидний туршилтаар гарган авсан 4 ордын идэвхжүүлсэн нүүрсний дээжүүдийг (ШОИН220, АТИН220, ШГИН220, НСИН220) анхдагч нүүрснүүдтэй харьцуулан SEM анализын аргаaр судалж гарган авсан дүнг 1-2-р фото зураг тус бүрт үзүүлэв.

Анхдагч нүүрснүүдийн SEM зургуудыг идэвхжүүлсэн нүүрснүүдийн зургуудтай харьцуулбал нүх сүв, зай завсар ихээр үүссэн, хайлж хөөсөрсөн аморф бүтэцтэй болсон байгаа нь харагдаж байна.

Шивээ-Овоогийн идэвхжүүлсэн нүүрсний SEM фоото зураг (1-р зураг Б) нь Нарийн сухайтын зураг (2-р зураг Г)-аас эрс ялгаатай байна. Шивээ-Овоогийн нүүрс нь үнс ихтэй, хүрэн нүүрс учраас органик масс нь халуун тэсвэрлэлт муутай амархан задардаг болно. Энэ шинж чанар нь бусад ордын нүүрстэй харьцуулбал: дэгдэмхий бодисын хэмжээ хамгийн их, карбонжуулалтаар үүссэн шингэн ба хийн бүтээгдэхүүний хэмжээ хамгийн их ба коксын гарц хамгийн бага байгаагаар батлагдсан болно (4-р хүснэгт). Иймд энэ нүүрснээс гарган авсан ИН-ний, өөрөөр хэлбэл хатуу үлдэгдэл дэх нүх сүвэрхэг бүтцэд органик массын нүүрсжилт ба полимержилтоор үүссэн нүх сүвэрхэг цул массын хэмжээ хамгийн бага байна $[15,16]$. Шивээ-Овоогийн идэвхжүүлсэн нүүрсэнд эрдэс хэсгийн эзлэх хувь хэмжээ их учраас эрдэс хэсгээс үүссэн хийн бүтээгдэхүүнүүд задралын бүсээс зайлуулагдах үед бий болсон жижиг хэмжээтэй нүх сүвүүд тодорхой хэмжээгээр түүнд агуулагдаж байна. 

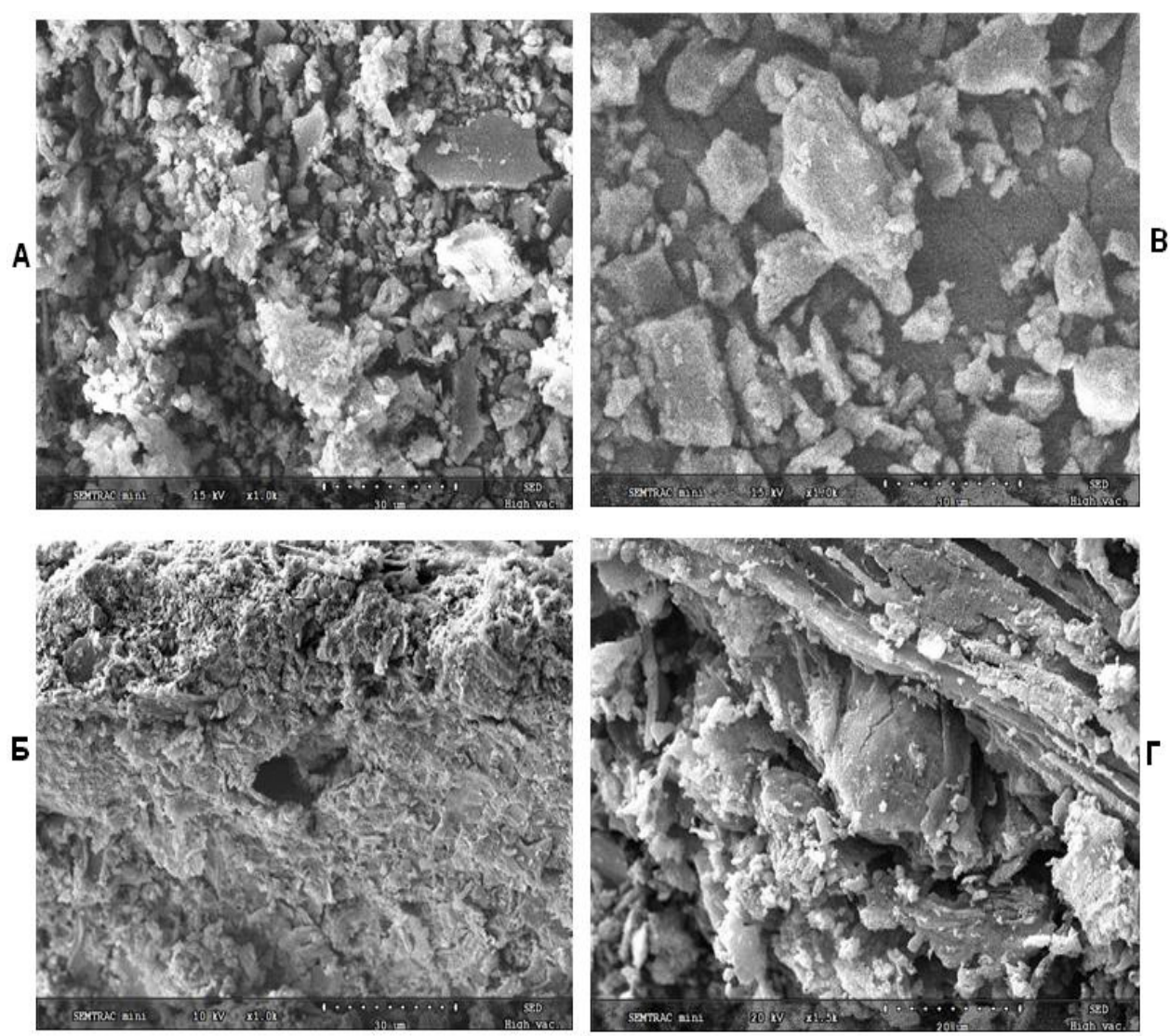

1-р зураг. Шивээ-Овоогийн нүүрс (А), идэвхжүүлсэн нүүрс (Б) болон Алагтогоогийн нүүрс (В), идэвхжүүлсэн нүүрс (Г) SEM фоото зураг.

Алагтогоогийн идэвхжүүлсэн нүүрсийг SEM фото зураг (1-р зураг Г)-аас үзэхэд нүх сүвэрхэг бүтцийн хувьд Нарийн сухайтынхаас ялгаатай бөгөөд түүнийг арай гүйцэхгүй байгаа боловч Шарын гол (2-р зураг Б) ба Шивээ-Овоо (1-р зураг Б)аас ерөнхий байдал нь өөр ба харьцангуй илүү нүх сүвэрхэг чанартай байна гэж үзэж болохоор байна. Алагтогоогийн нүүрс нь Нарийн сухайтын нүүрсийг бодвол үнслэг их ба дэгдэмхий бодисын гарц ихтэй байгаа нь түүний органик массын халуун тэсвэрлэлт, бөсөх чадварыг нь харьцангуй бууруулах ба иймд нүх сүвэрхэг бүтцээрээ Нарийн сухайтын ИН-ийг арай гүйцэхгүй байна [16]. 

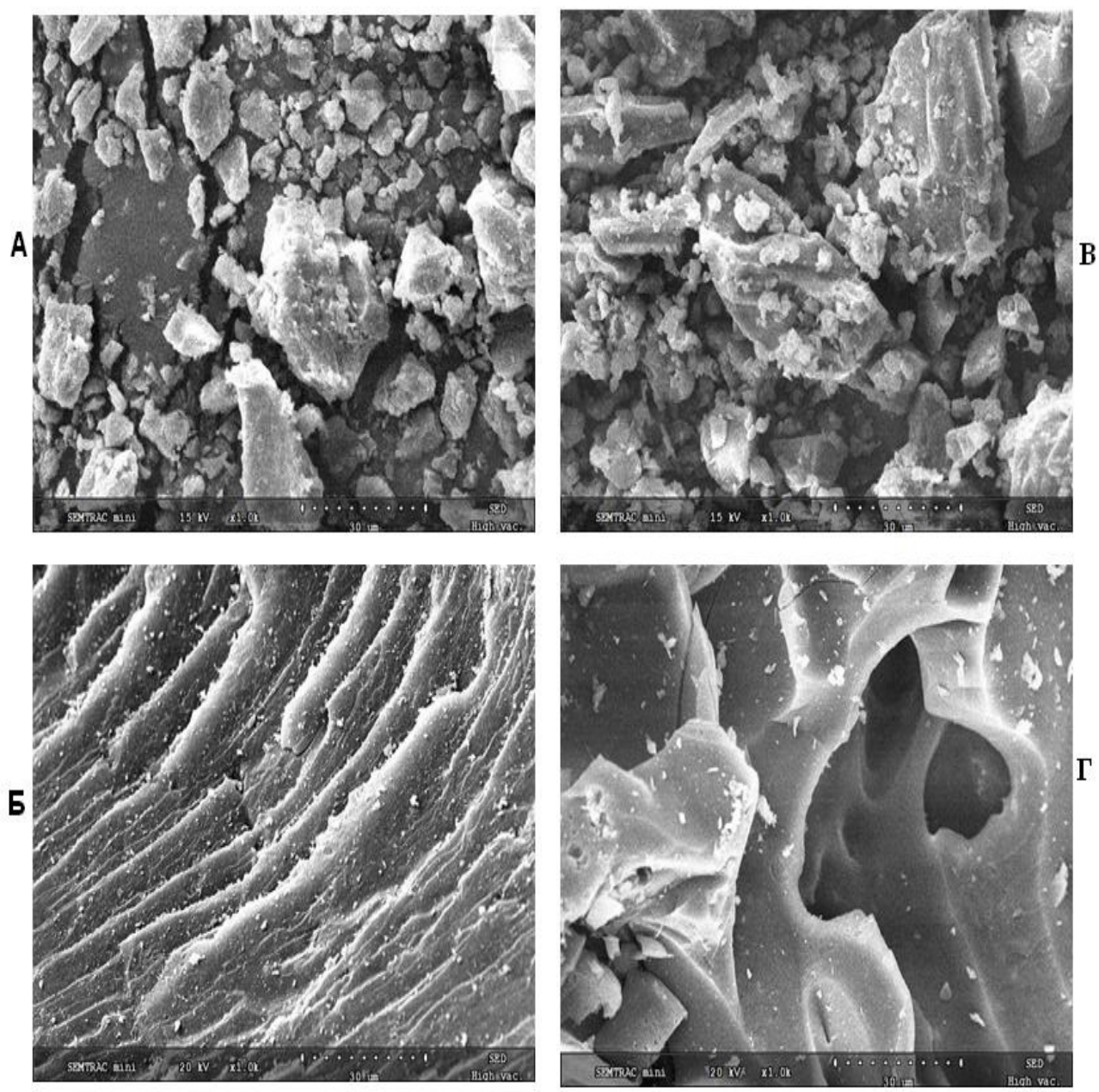

2-р зураг. Шарын голын нүүрс (А), идэвхжүүлсэн нүүрсний (Б) болон Нарийн сухайтын нүүрс (В) идэвхжүүлсэн нүүрсний (Г) SEM фоото зураг

Шарын голын идэвхжүүлсэн нүүрсний SEM фото зураг (2-р зураг Б) -аас үзэхэд том хэмжээний нүх сүвийн тоо цөөн, жижиг мезо нүх сүвүүд нилээд үүссэн байгаа ба нүх сүвэрхэг бүтцийн зураг нь 3 ордын нүүрсний идэвхжүүлсэн нүүрснийхээс нилээд өөр, судалтсан зай завсар ихээр үүссэн байгаагаараа онцлог байна. Нүүрсийг халуун уураар боловсруулах үед нүүрсний органик масс ба эрдэс бүрэлдэхүүний тодорхой хэсгүүд ямар нэг хэмжээгээр хайлаад царцсан байхыг үгүйсгэхгүй.

1-2 -р зургаас харахад, Нарийн сухайтын идэвхжүүлсэн нүүрсний нүх сүвэрхэг бүтэц нь хамт судлагдсан бусад нүүрсний идэвхжүүлсэн нүүрснүүдийнхтэй харьцуулахад их тод томруун харагдаж байгаа ба нүх сүвийн хэмжээ харьцангуй том байгаа нь уг ордын нүүрс бөсөх буюу хөөх чадвар сайтай сайн чанарын чулуун нүүрс болохыг илтгэж байна. Карбонжуулалтын явцад халуун задралын дүнд үүссэн шингэн ба хийн бүтээгдэхүүнүүд нүүрсний органик массад эзэлж байсан орон зайгаа үлдээгээд задралын бүсээс зайлуулагдсан, мөн усны уураар үлээлгэж идэвхжүүлэх явцад зарим нэг харьцангуй бага хэмжээтэй нүх сүвүүд -28 - 
бүрэн чөлөөлөгдсөн нь илэрхий байна [16]. Нарийн сухайтын нүүрсний дээж нь үнслэг хамгийн багатай мөн дэгдэмхий бодисын хэмжээ харьцангуй бага, нүүрсжин полимержих чадварын хувьд бусад нүүрснээсээ илүү нүүрс учраас халууны боловсруулалтын явцад органик масс нь халуун тэсвэрлэх чанар сайтай, микро нүх сүвэрхэг бүтэц харьцангуй сайтай бүхэллэг масс үүсгэсэн нь түүний SEM фото зургаас харагдаж байгаа ба бусдаасаа ялгарах гол онцлог нь болж байна.

\section{Дүгнэлт}

1. Судалгааны объктоор сонгож авсан 4 ордын нүүрсний болон тэдгээрээс гаргаж авсан идэвхжүүлсэн нүүрсний техникийн шинж чанаруудыг харьцуулан тодорхойлж карбонжуулалтын бүтээгдэүүний гарцыг тогтоов.

2. Судалсан 4 ордын нүүрсийг нүүрсжүүлэн идэвхжүүлэх аргаар гарган авсан бүтээгдэхүүнүүдээс Нарийн сухайтын идэвхжүүлсэн нүүрс нь $60.7 \%$ йод шингээх чадвартай, гадаргуугийн талбай 615 м²/гр байгаа нь ОХУ-ын Хус модноос гарган авсан $60 \%$ йод шингээх чадвартай БАУ-А маркийн идэвхжүүлсэн нүүрстэй ойролцоо шинж чанартай идэвхжүүлсэн нүүрс гарган авах боломжтойг тогтоов.

3. Туршилтаар гарган авсан Нарийн сухайт, Алагтогоо, Шарын гол, ШивээОвоогийн идэвхжүүлсэн нүүрсний нүх сүвэрхэг чанарыг SEM электрон микроскопийн аргаар судалж Нарийн сухайтын нүүрснээс гарган авсан идэвхжүүлсэн нүүрсний нүх сүвэрхэг чанар хамгийн сайн байгааг тогтоон энэ нь нүүрсний чанар органик массын халуун тэсвэрлэлт, нүүрсжин полимержих нүх сүвэрхэг цул масс үүсгэдэгт холбон тайлбарлав.

\section{HOM ЗYЙ}

1. B.Purevsuren. Coal is the main source of energy in Mongolia. Korean and Mongolian Energy Conference, Seoul, 26-29 June, 2007.

2. Б.Пүрэвсүрэн, Тавантолгой ба бусад нүүрсний гүн боловсруулалт, хэтийн төлөв, ШУАийн Физик-Математик-Химийн салбарын Бага чуулганаас УИХ-ын Ниймийн бодлого, БСШУ-ны байнгын хороотой хамтран зохион байгуулсан "Байгалийн шинжлэх ухаанМонгол улсын хөгжилд” хэлэлцүүлэг семинар, Улаанбаатар, 2011-1-18, хэлэлцүүлэгийн эмхтгэл х.96-120.

3. С.Долгор "Монгол орны томоохон ордуудын нүүрсний геохимийн судалгаа", Дэд докторын диссертаци, БНСЧСУ, Прага, 1976 он.

4. Б.Дашжамц, С.Долгор Монгол орны зарим томоохон ордын нүүрсний хими технологийн үзүүлэлтүүд, “Органик бодисын судлал” Монограф, №1,19.

5. Э.Нордов Исследование углей Шарын голского месторождения и гуминовых кислот естественного и искуственно окисленных углей, Диссертация на соискание ученной степени кандидата химических наук, Иркутск, 1972.

6. Д.Жамбал Структурные особенности и свойства основных компонентов углей в процессах сульфирования, Автореферат диссертации на соискание ученной степени доктора химических наук, Улаанбаатар, 1992.

7. Я.Даваажав, Б.Пүрэвсүрэн. Алагтогоогийн ордын нүүрсний шинж чанар ба пиролизын судалгаа. ШУА-ийн мэдээ, УБ, 2008, №4 х.3-11.

8. J.Narangerel., Sh.Monkhjargal., A.Ariunaa. Adsorption of heavy metal ions on oxidized carbon from coal. // ШУА -ийн мэдээ. УБ. 2004. №2. x 16-28.

9. Б.Авид. Хүрэн нүүрс, шатдаг занар, нефртийн хүнд үлдэгдлийн пиролиз, хийжүүлэлт ба дулааны уусгалтын судалгаа. Химийн шинжлэх ухааны доктор (Sc.D) -ын зэрэг 
горилсон диссертаци. УБ. 2007.

10. Б.Пүрэвсүрэн төслийн удирдагч, "Органик түүхий эдээс шингээгч, шүүгч материал гарган авах технологи” эрдэм шинжилгээний төслийн дуусгавар тайлан, 2005-2007 он, Хими, хими технологийн хүрээлэнгийн эрдмийн зөвлөлийн 2007-12-29-ий ба ТЭХЯны ШУТЗ-ийн 2008-5-8-ны хурлаар тус тус хэлэлцэж баталсан.

11. А.И.Камнева, В.В. Платонов. Теоретические основы химической технологии горючих ископаемых. Химия, Москва, 1990, с 270.

12. И.М.Глушенко Теоретические основы технологии горючих ископаемых, М., Изд-во Металлургия, 1990, с.71.

13. E.M.Suuberg, In "chemistry of coal convertion ", R.H.Schlosberg (ed.), Plenium Press, N.Y.1985.

14. K.C.Taupitz, Hydrocarbon processing, September, 1977, p.219-225.

15. Х.Кинле, Э.Будер. Активные угли и их промышленное применение. пер.с немец. Химия, 1984. с 215.

16. T.Budinova, E.Ekinci, F.Yardim, A.Grimm, E.Bjornbom, V.Minkova, M.Goranova. Characterization and application of activated carbon produced by $\mathrm{H}_{3} \mathrm{PO}_{4}$ and water vapor activation. Fuel processing technology 87, 2006, p. 899-905. 


\title{
SEM ANALYSIS OF ACTIVATED CARBONS
}

\author{
A.Ariunaa' ${ }^{1}$ B.Purevsuren ${ }^{1}$, Ch. Ganzorig 2 \\ ${ }^{1}$ Institute of Chemistry and Chemical Technology, Mongolian Academy of Sciences \\ a_ariunaa@yahoo.com,purevsuren_b@yahoo.com \\ ${ }^{2}$ Chemical Engineering Department of the National University of Mongolia
}

Coal samples of the Naryn sukhait, Sharyn gol, Shivee-ovoo and Alagtogoo deposits have been carbonized and activated by heat water steam and determined the main technical specifications of the starting coals and their activated carbons. The porosity structure of the prepared activated carbons have been investigated by SEM analysis and compared with the SEM analysis of initial coal samples. The activated carbon from Narynsukhait coal deposit characterizes higher adsorption abilities and more developed porosity structure than others. 